\title{
Getting into the Spirit of Things
}

\author{
SARA L. KNOX
}

UNIVERSITY OF WESTERN SYDNEY

Olu Jenzen and Sally R. Munt (eds)

The Ashgate Research Companion to Paranormal Cultures

Ashgate, Farnham, 2013

ISBN 9781409444971 RRP £85

A research companion maintains its distance and does not hold hands. When you are walking-as thinkers do, to clear the mind-a research companion trails respectfully behind, waiting to be called on. It is there when you want it and, thanks to digital print, manages to be spectre and substance all at once. In the case of this volume, very great substance: it would knock me unconscious if I lost my grip on it while reading on the couch. The Ashgate Research Companion to Paranormal Cultures is a big book about nebulous things that are difficult to corral and impossible to call to account. These things include the usual suspects of ghosts (or rather the lay professionals who conjure spirits and the punters who hunt them out or feel the faint impress of their presence), aliens (or rather the people who've seen them or the ships they travel in), and the monstrous animals that populate the field of crypto-zoology but also those 'traces from a non-human past' (Peckham, 102) that

Cultural Studies Review 2015. @ 2015 Sara L. Knox. This is an Open Access article distributed under the terms of the Creative Commons Attribution 4.0 Unported (CC BY 4.0) License (https://creativecommons.org/licenses/by/4.0/), allowing third parties to copy and redistribute the material in any medium or format and to remix, transform, and build upon the material for any purpose, even commercially, provided the original work is properly cited and states its license. 
haunt our genes and the spirit of musical genius that moves the untrained hand to write a new piece by Liszt. Other otherwordly entities are missing from the collection, however. Demons don't get much of a look in, except as bit players in legend-trips on internet sites aimed at the paranormal faction. Nor does the 'sublime buzz of otherness', (18) as co-editor Sally Munt phrases it, come in the shape of getting one's buzz on since hallucinogenic gateways to the paranormal are conspicuously absent from discussion.

With a standout introduction to the whole by Munt and editorial essays to frame each of the three parts of the book, the collection is at first blush neatly packaged. When you read from cover to cover, however, form unravels. Partly this is due to the uniform length of the contributions which often end before they've begun. Like a castaway doing their first anxious scramble from the western to the eastern shore of their desert island, one is delivered from one confounding view of the deep blue sea to another. Nor can the division of the book into three (epistemologies of the paranormal; the paranormal's registration in and impact on social change; and the phenomenology and aesthetics that give it shape, voice and form) contain the noisy constituency of its parts. For the question remains: how do you give shape to a void?

Formlessness might be considered less a weakness than a strength of a work the anatomy of which (collection, survey, companion) reflects the supplemental logic of the paranormal. Paranormal Cultures keeps company with things that are contradictory: things that are disjunct and connected, anachronistic and state-of the art, quotidian and bizarre. Not for nothing did The X-Files partner Scully the skeptic with Mulder the believer. Veering between an episodic monster-of-the-week structure and a through-plot yoking government conspiracy to familial drama (what did happen to Mulder's little sister?), The X-Files aptly scopes out the cultural logic of the paranormal: while the specific instance can never 'prove' the general rule the drive to instantiation must go on. As Angela Voss puts it in her chapter on the contemporary epistemology of the paranormal, this is the 'crisis in the nature of thought when it finds itself confronted with non-rational experience'-in Kantian terms, the 'negative epistemology' of 'spiritual knowledge'. (141) Indeed, in developing his mature account of metaphysics, Kant considers the paranormally talented Swedenborg, who knew that a fire had broken out in Stockholm though he 
was at a dinner party in Gothenberg at the time. 'One must investigate' the phenomenon, writes Kant, for 'as long as a single case is possibly genuine' one must 'not pour all of it out' but only that which is necessary? sufficient? indicative? (Gregory Johnson's translation does not help us here) 'to purify partially false observations and more easily discover the ground of error'. ${ }^{1}$ But where to find the baby in the paranormal bathwater? The ground of error is impossible to discover when 'we are talking of phenomena that sits outside the manner of thinking that requires proof'. (Voss, 141)

Proofs of paranormal phenomena are not to be had, and don't I know it. I know people who have seen ghosts but have never seen one myself. My sister Elizabeth has an ecstatic bent and has seen more than a few ghosts in her time, including an Edwardian family picnicking on a hillside above the rail line where it disappears into the tunnel at the Ngauranga Gorge, near Wellington. In the early 1970s, when my friend Robbie Murphy and I were lying in the bottom of a boat in Paremata Harbour, we saw a flying saucer spinning very high and far away in a washed out summer sky. But just a few nights ago when I was talking to my sister in New Zealand she said, 'it didn't spin, it flip-flopped-it was almost certainly a collapsed weather balloon'. When I protested, 'How do you know?' she replied, 'Because I was there. Don't you remember?' And there went one of my stock stories of the paranormal, blown out of the sky and leaving the junk that troubles all who dig in the cemetery of experience: the vissicitudes of memory and the ongoing temptation to story. But why that story or that misremembering remain pertinent questions in themselves, the kind of questions that demand a volume like the Ashgate Companion to Paranormal Cultures to do something different from the scholarship in parapsychology, histories of hysterias and their complex cultural incarnations, and popular compendiumsonline and off-of the unexplained. The role of the companion is to mediate between a literature of rationalisation and a literature of belief.

In 1996, when I was still running a fever after major surgery, I set off to Brisbane to do a spot of research on paranormal cultures at the Mutual UFO Network Australia Conference, an annual gathering of alien abductees. Arriving off a late flight, my bags were sent up in one elevator while I went up in another, where I was joined by a young American woman, as tan and doe-eyed as I was pale and exhausted. As the lift jerked into its ascent she leaned close and said, 'I don't think 
I'll ever get used to this feeling of going upwards'. A few minutes later I was standing at the window of my hotel room with a glass of water in one hand and my antibiotics in the other. I remember thinking, as I popped a painkiller, that I shouldn't make too much of a weird first encounter. But then came my second encounter. I was at breakfast when a very tall, very thin fellow came to my table. He was immaculately suited and coiffed, like a maître d' or a primetime television FBI agent. Looking at my coffee rather than at me, he asked whether I'd perhaps seen Simon Wilson. I said I'd only just registered and hadn't met many people yet. He nodded along with this for a while then winked and tapped the side of his nose. 'The thing of it is,' he said, sotto voce, 'he may not be travelling under his own name.'

I don't remember what I replied to that. There is a blank there, just as there is a blank for my end of most the conversations I had over the following days. What, for instance, did I say when the woman sitting next to me at the lecture on alien technology told me she could remember her sister drowning when the waters rose and the 'great city' of Atlantis sank and that we'd all been Little Greys and Reptilians sometime in the course of our many incarnations? This came as alarming news to the woman sitting behind us who'd been abducted by both types in her time and now had no idea whether she was an Us or a Them. After two days of this I was ready to flee. But it wasn't the florid craziness that got me in the end, it was the people new to the network, men and women who stepped shyly up to the podium to tell the story of the one strange thing that had happened to them in an otherwise ordinary life. Not obviously crazy, they were the credible witnesses to the incredible. I had no idea what to do with them.

The abductee conference is my most boondoggling experience of the paranormal (not counting the CIA agent I met at Disneyworld but that's another story). My benchmark measure for the incredible, however, comes from when I was standing on a remote beach in Abel Tasman National Park without a sunhat, eyes half shut against a brightness that wanted to turn me inside out, thinking $I$ wish a had a hat. At which point a black baseball cap came skudding along the sand to fetch up against my foot. The cap was plain black without a logo and that detail made the whole thing even more mindboggling-a logic-defying coincidence to beat the best of them. 
The story of the sunhat presents to you, dear reader, the problem that the least mad speakers at the MUFON conference presented to me. It forces you to ask whether I can be trusted, whether I'm a credible witness to the incredible. If, as Sally Munt suggests, you approach the matter 'with curiousity, and with ... senses attuned to the irrational' (1) then you might be halfway towards acceptance or minimally an 'agnostic standpoint that can incorporate contradiction'. (4) Indeed, much of paranormal culture works by second-order reference, by a willingness to believe in the storied experience of others. Whether traced to a blurred photo or pixelated video image, everything rests on how the thing is accounted and who does the accounting. As John Harvey's percipient piece on spirits captured by sound recording, film and the digital image suggests, it is the 'who' not the what or the why of the evidence that matters: 'belief in the veracity of an image or sound is based ... on one's faith in the claims made by the person who recorded the anomaly'. (61)

This is why the 'I-know-someone-who' or 'a friend of a friend' factor is so well documented by scholars of folklore who study ostension, the process by which legends are extended by homage, imitation and ritual staging. But in a postindustrial world characterised by 'subjectivisation' (Partridge, 42) rather than collective storytelling, our experience is, at least in part, a matter of introjection. Thus for the scholars in this collection laying claim to the 'agnostic standpoint' means a cautious weighing of the second-order evidence-the evidence of beliefs and practices or the social and media trends that reflect them, a third-order of phenomenon but one on which the methodology of paranormal studies can at least get a firmer grip. Thus: Annette Hill's ethnography of the paranormal in popular culture in Southeast England focuses on the productive participation of audiences in 'ghosthunting' reality television formats and tourism enterprises; Gerhard Meyer's account of the impact of American style, tech-savvy ghosthunting on the growing number of groups in Germany dedicated to the same thing; and Andrea Molle and Christopher Bader on the global homogenisation of paranormal culture in Italy, where the 'import of foreign cultural elements' enlivens both a dormant gnosticism and the Catholic preoccupation with symbol and liminality. (132) Mediums and mediumship also feature significantly, giving a new twist to McLuhan's the medium is the message. 
Esther Peeren examines the televisual medium and the politics of mediumship'. Wendy Cousins provides a model contribution on the Irish literary renaissance and the strategic power of the paranormal. Spirit communication allowed Yeats, Maude Gonne, and James and Margaret Cousins the means to articulate profane 'paradoxes of identity and territory' through a process of reenchantment and the invention of 'a new province of the imagination'. (264) Jennifer Fisher writes about the usefulness for art historians of psychometric technique. The adept can sense by touch the 'imprint' of past events on objects, a sensitivity that sometimes provides suggestive solutions to the mystery of provenance for artworks about which little is known. The chapter by Janet Baldwin on the gynocentric culture of mediumship in a Western Australian urban community also deals centrally with the strange gifts of the medium. The Fisher and Baldwin chapters are distinctive in that they are the only two in the collection that are unequivocally 'insider' accounts. That is to say, the authors believe they are reporting from, not about, the border between everyday life and the paranormal.

Baldwin's chapter is a participant observer's view on the cultural space in which the dead speak. It provides an account of the disembedded time and place that is the sitter's bodily experience during trance alongside an account of the subcultural scene comprised by the trance circle. Although in many ways a standard expansion to the literature of subcultural studies, the chapter is an unaccountably confronting read despite the gentleness of the Spiritualist culture it evokes. The trance medium's circle is described as a 'protected and protective space' (356) for the women involved, and the language of the chapter-and of the medium herself when in trance communication with 'airside'-echoes the cultural work of women's consciousness raising groups of the 1970s and 1980s. Just out of a trance state in which her spirit guide has been talking about the importance of open communication and emotional trust, the medium describes her experience of connection to 'airside' as 'a place of sanctuary, a place of revision, a place to choose'. ('Mary', 357) These terms are eerily familiar, as is the description of the care the women in the circle take for the trance medium as they husband her throughout the sitting and the long waking through which she must 'return to consciousness gently and in her own time'. (355) 
If I was to read the subculture of the trance medium circle through other disciplinary frames it would be hard to miss its similarity to the 'domestication of heaven' that historian Ann Douglas finds in the 'consolation literature' that was popular in nineteenth century America. Elizabeth Phelps Stuart, an early follower of Spiritualism, claimed that her spirit guide had told her in great detail what heaven was like: what people ate, the work they did, the style of hats they liked and which musical pieces were popular. ${ }^{2}$ In the nineteenth century death was neither foreign nor strange and heaven resembled a fashionable suburb in a major American city, a comfortable projection to the other side of familiar social expectations and mores. Baldwin's chapter has no pretensions to describing heaven but it does articulate the continuity of lifeworld and deathworld in ways that provide a very particular exemplum of the 'epistemological individualism' and 'subjectivisation' that Christopher Partridge identifies as the bedrock of both contemporary Western alternative religions and 'occulture'. (41-3)

In the November 2014 news cycle, a story about the work of a Swiss research team did the rounds. The research project unpacked the 'feelings of presence' (FOP) that the bereaved experience routinely and the more rare encounters of mountaineer or arctic explorers with a shadow companion on the ice beside them. The experiment involved giving subjects remote control of a robotic arm that they used to lightly touch their own back. Across time the touch signal was delayed so that cause and effect drifted progressively further apart until the subject began to feel the touch as coming from something and someone else, an invisible other. The subjects reported a feeling of presence so intense and upsetting that they called for the procedure to be terminated. They had begun to perceive their own body as the spectral body. The researchers concluded from the experiment that angels, demons and ghosts are figments, phenomenological artefacts, nothing but a displaced orientation to our own body brought on by situations of extreme stress. ${ }^{3}$ Reading that report made me want to weep and lie down with my face to the floor like a penitent. The world seemed somehow smaller and more confined. As if, far off, a door had been quietly closed, then locked. 
Associate Professor Sara Knox is a member of the Writing and Society Research Group in the School of Humanities and Languages at the University of Western Sydney.

\footnotetext{
-NOTES

${ }^{1}$ Gregory R. Johnson, 'Kant on Swedenborg in the Lectures on Metaphysics, Part 1', Studia Swedenborgia, <http://www.shs.psr.edu/studia/index.asp?article_id=71>.

${ }^{2}$ Ann Douglas, 'Heaven Our Home: Consolation Literature in the Northern United States, 1830-1880', American Quarterly, vol. 26, no. 5, December 1974, pp. 496-515.

${ }^{3}$ Sarah Knapton, 'Ghosts Created by Scientists in “Disturbing” Lab Experiment', The Telegraph (UK), 6 November 2014, <http://www.telegraph.co.uk/science/science-news/11214511/Ghosts-created-byscientists-in-disturbing-lab-experiment.html>.
}

\section{-BiBLIOGRAPHY}

Douglas, A., 'Heaven Our Home: Consolation Literature in the Northern United States, 1830-1880', American Quarterly, vol. 26, no. 5, December 1974. doi: http://dx.doi.org/10.2307/2711887 Johnson, G.R., 'Kant on Swedenborg in the Lectures on Metaphysics, Part 1', Studia Swedenborgia, <http://www.shs.psr.edu/studia/index.asp?article_id=71>.

Knapton, S., 'Ghosts Created by Scientists in “Disturbing” Lab Experiment', The Telegraph (UK), 6 November 2014, <http://www.telegraph.co.uk/science/science-news/11214511/Ghostscreated-by-scientists-in-disturbing-lab-experiment.html>. 